\title{
How Rural Development Programmes Serve for Viability of Small farms? Case of Latvia and Lithuania
}

\author{
Armands Veveris ${ }^{1}$, Vaida Šapolaite ${ }^{2}$, Agota Giedrė Raišiené $\dot{2}^{2}$, Yuriy Bilan ${ }^{3}$ \\ ${ }^{1}$ Institute of Agrarian Resources and Economics, Riga, Latvia \\ ${ }^{2}$ Lithuanian Institute of Agrarian Economics, Vilnius, Lithuania \\ ${ }^{3}$ Rzeszow University of Technology, Poland
}

\begin{abstract}
The analysis of structure of agricultural sector shows a poor viability of small-scale farms in new EU member states despite support of the Common Agricultural Policy. Considering this problem, the aim of the article is to identify indicators that can be used to show changes in the viability of small farms in order to bring policy makers more attention to this very important group of farms in the context of the agricultural economy in Latvia and Lithuania. For this purpose, 4 economic indicators were selected, analyzed and their impact to the change in the level of viability of small farms during 2007-2016 was assessed. The research based on the data of Farm Accountancy Data Network and Farm Structure Survey, using statistical data comparison, systematic indicator selection and mathematical induction methods. The results shows that despite growing of the rate of subsidies on investment and improving income level in small farms over the observed period, the viability of small farms remains heterogeneous and insufficient to contribute in constructing more resilient and sustainable agricultural sector both in Lithuania and in Latvia. Thus, in the upcoming Rural Development Programming period, the priority should be given to small-scale farms since they play a significant role not only in development of viability of agriculture in general but also are important to agricultural sustainability.
\end{abstract}

\section{Keywords}

Rural development, small farms, viability, agricultural sustainability.

Veveris, A., Šapolaitė, V., Giedrè Raišienè, A. and Bilan, Y. (2019) "How Rural Development Programmes Serve for Viability of Small Farms? Case of Latvia and Lithuania ", AGRIS on-line Papers in Economics and Informatics, Vol. 11, No. 2, pp. 103-113. ISSN 1804-1930. DOI 10.7160/aol.2019.110210.

\section{Introduction}

European Commission (EC) gives a lot of attention to the strategies of European Union (EU) member states (MS) development. As in the majority of countries, Lithuania and Latvia approved long-term perspective sustainable development strategies called "Lithuania 2030" and "Latvia 2030" respectively. The priorities important for functioning in the EU are defined in the strategies. It is also anticipated to increase the viability of rural regions and to reduce social and economic disparities. Nevertheless, according to the Competitiveness Index of 20152016 and 2016-2017, the Baltic States are still in the lowest ranking group. This means that even by following Common agricultural policy (CAP) it is not simple to ensure the sufficient competitiveness of particular country. Poor country's competitiveness results are mostly influenced by poor viability indicators of regions, especially rural areas (Rivza, Kruzmetra, 2017; Melnikienè et al., 2018). According to Tvaronaviciene and Gatautis (2017), the health of local economy should be seen as one of the key factors for maintaining viability, thus economic activity plays a significant role in ensuring viability.

In the recent years, evaluation of economic activity of small farms has received a lot of attention as it was observed that small farms often depend on EU subsidies to survive (Hanrahan et al, 2018; Ryan et al., 2014; Poór et al., 2018). Furthermore, small farms have the potential to grow both in size and capability, become more competitive and be an economic core in agricultural structure. Thus, more attention has to be paid to their economic development, while EU support has to contribute to the decreasing of the variability in farm income.

The direct payments helped to reduce the income inequality among farmers of different economic size (Latruffe, Bojnec, 2013; Namiotko et al., 
201 Kharlamova et al., 2018), nevertheless, some of them are too small to be self-sufficient in the terms of efficiency and profitability (Vrolijk et al., 2010). They cannot supply a large volume and homogeneous agricultural production, thus generate not enough profit which has become the standard of modern farming. Small farms can flexibly adapt to various environmental and market changes and are playing a great role in rural employment. However, competitiveness of small farms is determined by possibility to acquire the modern agricultural machinery and new technologies, to improve farm's infrastructure, etc. (Gioia, Rioufol, 2017; Soumaya, 2012). So though small farms can be economically and socially viable and valuable to society (Gołaś, 2017; Moroz, et al., 2014; Samberg et al., 2016), they need support. Therefore, two problems need to be addressed, 1) whether the support actually has a positive effect on the viability of small farmers; 2 if so, which level of support is sufficient to reach small farms' long-term viability is relevant. As was mention earlier, there are researches proving the need of support for small farms. Nevertheless, the CAP support measures is aimed at promoting all agricultural areas and farms of different size, the situation is specific in such EU countries with extremely dominating number of small farms as in Lithuania or Latvia which small farmers account for the majority of support beneficiaries and receive almost smallest support in EU (Veveris, Šapolaitė, 2017). Classical economic indicators in the agricultural sector are among the most suitable for measuring the economic viability of small farms. Thus, the paper is aimed to analyse the relationship between four indicators: farm income and output, subsidies on investment and EU support by Rural Development Programme (RDP) in Latvia and Lithuania, and to reveal the dynamics of small farms viability in period of 2006-2017.

\section{Materials and methods}

Main concepts and context of measuring small farms viability

An exploration of the economic viability of French micro farms research shows that by invoking saving investment, self-organization and use of secondary materials, even the smallest, such as family farms can be economically viable (Morel et al., 2017). On the other hand, the necessity to save leads to work overload which negatively affect the perspectives of small farms viability. In different countries, small farmers make different decisions on solving the problem of lack of resources. For example, in France cooperation is evaluated positively (Morel et al., 2017), whereas in Lithuania, as our previous research show, neither small nor larger scale farm holders are keen on cooperating (Raišienè et al., 2018). Other studies (Guiomar, et al., 2018; Samberg, et al. 2016) focus on analysing the contribution of small farms to local food supply, food security and food sovereignty and they are often seen as an alternative to large and specialized farms. However, it can be noted that small farms are successfully developing mixed agricultural production, predominantly with parttime employment.

However, a tendency of broadening of the agricultural production and/or producing premium class product sector's variety is developed by large scale farms in the whole western world. According to Kirschenman et al. (2008), due to this reason, medium and small farms gradually disappear because they lack the capacity to both compete in a rapidly changing market of wide variety and specialize in highest class product market. As this process is observed in various countries with different political decisions, researchers claim that farm viability should not be directly linked to political decisions. On the contrary, sustainability of agriculture requires the opposite. Scientists note that economic viability is a favourable indicator to determine whether a farm will remain active in the near future. However, this does not necessarily forecast the long-term sustainability of the farm which depends not only on economic changes and circumstances but also on social capital and social inclusion (Hooks et al., 2017). Thus, sustainability in agriculture is often described as a consequence of national and international politics which puts into balance the economic, social and ecologic priorities. The authors also take note that the demographic problem is often concealed when speaking about the sustainability of agriculture. Preserving the vanishing small farms becomes increasingly harder. Thus, it must be understood that taking care of the small farms' viability is not only the country taking care of its citizens, it is mandatory to take into consideration the cost of demographic changes on the society, economy and ecology (Seghezzo, 2009; Dillon et al., 2016). Along with the decrease of rural population, the whole rural infrastructure is waning away which is harder to recreate than uphold.

The scale of the problem is quite large. According to the data of Eurostat, there are approximately 2 million small farms in the EU which cannot survive without subsidies. In order to fundamentally 
strengthen them, the problem must be solved systematically, i. e. taking care of the viability of the whole agricultural sector, taking into consideration the influence of abovementioned factors of sustainability and resilience. As Hooks et al. (2017) state, all these areas are intertwined and measuring the progress of one of them, ignoring the situation in another is inadequate.

The majority of recommendations contain an urging to produce more in order to reach farm viability. However, research shows that small farm viability is influenced not so much by the amount of production but by the structure of the farm and type of production (Lyson et al., 2008). On the other hand, economically "non-viable" farms are often very environmentally sustainable and vice versa (Macken-Walsh, Roche, 2012; Hooks et al., 2017). Therefore, various opinions are expressed in the scientific discussion on measuring viability and issues of it forecasting. For example, O’Donoghue et al. (2016) noticed that agricultural viability is comprehended differently in Northern and Southern regions while Hooks et al. (2017) pointed out that even in the same region, measurements could be complicated by the lack of unified system for the evaluation of agricultural viability.

Sustainability can be named as viability with environmental goals; and attempt to balance the economic, social and environmental goals together with adoption of innovation, though unified methodology on measuring progress is also absent (Guiomar et al., 2018; Dillon et al., 2016). Nevertheless, researchers place more and more value on socio-cultural capital, not just the economic capital when speaking about agricultural sustainability (e.g. GaldeanoGomez et al., 2016). Thus, small farms viability, as a core element on social dimension of sustainability, is extremely important in whole sustainable development of states agricultural sector.

Finally, the small farms support and increasing of its viability is linked to the resilience of the agricultural sector. It should be highlighted that the content of the resilience concept is also defined differently due to its nature while its evaluation causes problems just like the viability and sustainability discussed earlier. Essentially, resilience is a capacity of a system to absorb disturbance and reorganize while undergoing change so as to easily retain essentially the same function, structure, identity and feedbacks" (Walker et al., 2004, p. 4; Folke et al., 2010). Literature also insists that resilience cannot be measured or expressed only quantitively because resilience is formed by the ability of farms to maintain viability and seek for sustainability. When measuring the viability and sustainability of farms, economic resilience could be evaluated as an adaptational skill, mandatory in times of adversity and crisis (Hooks et al., 2017). Emphasizing the importance of social aspects on the economic resilience of agriculture, some characteristics stand out, such as the farmers' ability to cooperate, participation in making various, including political level decisions, membership in different organizations etc. On the other hand, small farms also benefit from slow way of life which is developing as an alternative to intense farming. Widely spreading propagation of organic farming allows small farms to find a place in the market dominated by large scale farms, hereby providing products with exceptional qualities that can be reached through active participation in EU RDP.

\section{Rural development challenges}

In order to provide all farmers with equal and favourable conditions, EU financially supports agriculture through various dedicated programmes. Rural development policy, known as the "second pillar" of the common agricultural policy (CAP), is based on EU funds' and national funding's co-financing principle and implemented through multiannual programming periods. The current programming period 2014-2020 offers a total of 19 different RDP measures from which MS and their regions may choose, designing sub-measures suitable to local needs (StanczukGalwiaczek, 2018). Due to programmes covering all EU member states and significant amounts of funds, both political institutions and scientists analyse and evaluate the success of rural development policy implementation and assimilation of support (Caruso, 2015).

Unfortunately, financial support programmes are not always as effective as expected: research shows that final support reaches only a third or less than half of farms (the majority of which are large scale), calculating by area (Sarvašová et al., 2017). The effectiveness of EU support is a problem that is being solved by politics on the level of different countries and the EU as a whole. This problem is not only complex but includes contradictions which prevent the fluent strive for common goals of the EU policy. On one hand, financial support to agriculture is expected to improve the condition of farms, the changes of which is measured through economic indicators. In turn, economic interests stimulate farms to increase agricultural output which is obtained by increasing the intensity of agricultural 
activity. However, such intensification negatively affects the condition of the land, thus violating the environmental goals. On the other hand, even though economic indicators allow defining the condition of economic resilience of a country, evaluating the condition of social welfare using same indicators would be difficult. In addition, they do not say anything about the country's success in maintaining population and its variety in rural areas (Hooks et al., 2017). As it is evident, support for agriculture creates a conflict between different poles of EU. Therefore, in spite of food safety, energy security and climate change being seen as the most relevant challenges of current times by EU, some specific difficulties prevent contribution to overcoming these challenges.

The problem of agricultural development among and within countries is extremely important in the EU because as much as 80 percent of the EU territory consists of rural areas with half of its population living in these areas. However, according to Eurostat (2017), rural citizens are more at risk of poverty or social exclusion than urban inhabitants (according to statistics obtained by Stanczuk-Galwiaczek (2018), 42 and 25.5 percent respectively). Emigration and migration also negatively affect the viability of rural areas and vice versa. To solve these problems, the 2014-2020 RDP, promoting social inclusion, poverty reduction and economic development in rural areas is signed as one of six priorities (European Commission, 2016). Noted amongst the priorities are topics like resilient economy, sustainable management and viability of all types of agriculture. Although Lithuania and Latvia as well as the majority of other new MS tend to allocate more funding to priorities of social inclusion, poverty reduction and economic development than old MS, viability indicators as shown by research are unsatisfactory (StanczukGalwiaczek, 2018). According to the results obtained by other researchers, while examining effects of various types of subsidies on investment, it was noticed that the investment (especially of small or medium scale farms) is viably important on the current farm production level which depends on past investment decisions. Annual investment decisions affect both the current level of capital, and future production (Svoboda et al., 2016). Talking about the small farms structure and tendencies, same authors used to examine the viability of farms on the basis of Farm Accountancy Data Network (FADN) data and revealed that investment had significant impact on income, which represents possibilities for extending new property (Svoboda et al., 2016). It is also noted that the subsidies for investment of countries with a high asset value do not reach the growth rate of such values. Clearly, this is due to the overall economic level of those countries where investment growth is not dependent on the subsidies provided (Guiomar, et al., 2018)

Thus, the article aims to investigate the variability of farm income and the effect of farm size on gross investment in the agricultural sector while analysing farm income, output and gross investment indicators. Their more detailed analysis leads to assumptions and recommendations for policy formation.

\section{Methodological approach}

In order to analyse the small farms viability, Lithuanian and Latvian agricultural structures through 4 selected economic indicators of viability were under comparison.

Physical measure (the $1^{\text {st }}$ indicator) such as gross farm income $(G F I)$ was calculated per one annual work unit AWU:

$$
A_{G F I=\frac{\sum_{j} G F I}{\sum_{j} A W U},}
$$

where:

$A_{G F I}$ - average gross farm income measured by farm net value added per $A W U(F N V A / A W U)$;

$j-$ set of farms.

The $2^{\text {nd }}$ indicator - standard output $(S O)$ :

$A_{S O}=\frac{\sum_{j} S O}{\sum_{j} U A A}$,

The $3^{\text {rd }}$ indicator - gross investment $(G I)$ :

$A_{G I=\frac{\sum_{j} G I}{\sum_{j} U A A},}$

The $4^{\text {th }}$ indicator - subsidies on investment $(S$ on $I)$ per one hectare of utilised agricultural area $(U A A)$ can clearly be used:

$$
A_{S \text { on } I=\frac{\sum_{j} \text { S onI }}{\sum_{j} U A A}}
$$

where:

$A_{S O}$ - standard output is the average value of the agricultural output at the farm-gate price of each agricultural product (crop or livestock) in a given country;

$A_{G I}$ - gross investment is purchases (expenses on land, improvements, machinery, building) minus sales of fixed assets plus breeding livestock change of valuation. 
$A_{\text {Son I }}$ - subsidies for investment are regarded as part of the RDP payments.

This estimation was made using the FADN - an instrument for evaluating the income of agricultural holdings; and Farm Structure Survey (FSS) which provides detailed information on production structure of the EU farms with the period of 2007-2016. While calculating at the national level the data was taken from Eurostat. Meanwhile, at the farm level the FADN data was used. The structure of the farms is being analysed, using distribution based on farms economic size, where standard output used as the criterion applied. Taking into account the purpose of the paper and the actual structure of the farms in Latvia and Lithuania, the farms with SO value from 2000 up to 8000 EUR are considered as small.

\section{Results and discussion}

The small farms are identified with the aim of highlighting their need for special rural support measures by RDP, applying the economic size criterion seems to be most appropriate (Lowder, et al., 2015).

In order to identify and evaluate viability and the competitiveness contribution of smallscale farms to the welfare of the country, their potential, and the development of farmingrelated employment was based on FADN data and the groupings selected according to the following groups. Six different groups have been defined according to their economic size: $2000<8000$ EUR; $8000<25000$ EUR; $25000<50000$ EUR; $50000<100000$ EUR; $100000<500000$ EUR; $\geq 500000$ EUR.

According to the FSS data (2016), the share in agricultural output of small farms (SO $2000<8000$ EUR) in Latvia was equal to 7\% in the total production and in Lithuania - 11\%; employment $-26 \%$ and $30 \%$ respectively. Latvia and Lithuania are MS characterised by a large number of small farms. This means that they play a significant role in supporting rural employment, they are important for local production, particularly contributing to territorial development (Gioia, Rioufol, 2017).

Many scientists agree that small farms can indeed be viable if they are planned well (Moroz et al., 2014). This means that small farms also need more and better support. Development of the gross farm income over the past ten years has highlighted a more equal distribution of income in 2016 compared to 2007 both in Latvia and Lithuania; although in Latvia there are still larger differences between different size groups (Figure 1). In the largest size group the average income was

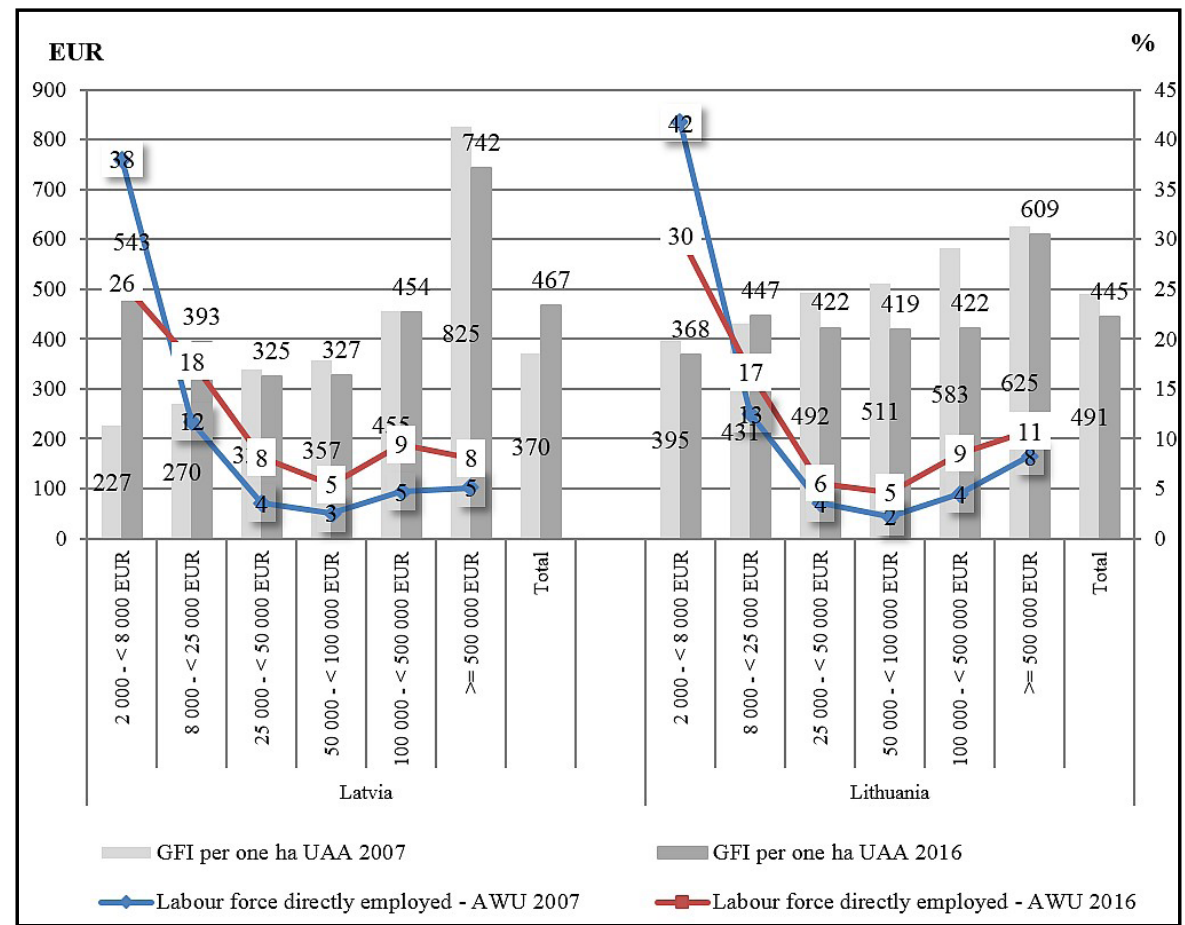

Source: Calculations based on FADN data $(2007,2016)$.

Figure 1: Gross farm income per one AWU and labour force directly employed (AWU) in Latvian and Lithuanian farms in 2007 and 2016. 
by $137 \%$ in Lithuania and by $159 \%$ in Latvia higher than national total in those countries. Although the income change of farms has improved slightly during the 2007-2016 period: income of small farms increased 2.4 times in Latvia and decreased by $6.8 \%$ in Lithuania. These differences are based on the capacities of small farmers to absorb support, which depends on provided opportunities for small farms to reach it at national level.

Despite these differences in investment, the employment of small farms remains an important aspect in both the Lithuanian and Latvian agricultural structures.

The share of AWU in Latvian small farms is $26 \%$, in the largest group $-8.1 \%$, in Lithuania $-30 \%$ and $10.8 \%$ respectively. On the other hand, a high proportion of small farms play an important role in supporting rural employment and contributing to territorial development, providing specialized local products and/or higher quality products as well.

According to the Figure 2, results show, that on average, SO per one UAA ha in small farms in Latvia was equal to 397 EUR/ha in 2016, i.e. by $51 \%$ less than in total average; in Lithuania - 646 EUR/ha and by 14\% less in comparison to total in 2016. From 2007 to 2016 the average SO of small farms in Latvia increased by $41 \%$ and by $34 \%$ in Lithuania. It was primarily influenced by the volatility of input and output prices and changing of yields. A common trend shows that the small farms' SO per UAA ha is significantly lower than in the largest farms.
It is difficult to coexist for small farms, which are still prevalent in the EU, among farms of other economic size. Nevertheless, the issue of the size of farm is still of high importance, as small farms largely maintain social dimension of agricultural sustainability and actively engage in production on farms. Most often scientists indicated the importance of gross investments and subsidies on investments in small farms, the higher income is one of the factors which improve the level of small farms viability and their ability to develop in countries (Morkūnas et al., 2018; Soumaya, 2012). The levels and dynamics of the investment depend on the size of the holding and their financial situation. Large scale farms have a better financial condition; they have more financial resources to spend on investment, to modernise of production processes faster. In 2007 Latvian and Lithuanian larger farms bought twice more agricultural machinery and buildings than small farms. It should be noted that the average gross investments in farms of all sizes are increasing annually. In 2016, gross investment per one UAA ha in small farms was equal to $386 \mathrm{EUR} / \mathrm{ha}$ in Lithuania, i.e. 4 times higher compared to 2007; and $338 \mathrm{EUR} / \mathrm{ha}$ in Latvia, i.e. 3.8 times higher in comparison to 2007. In the old EU member states the change is not so significant as in Latvia or Lithuania. However, the current level of gross investment is about 7-8 times higher (or by $87 \%$ lower than in EU-28 on average), which reflects the greater viability and activity of small farms based on the long-term sustainability that most promotes the resilience of the agricultural sector.

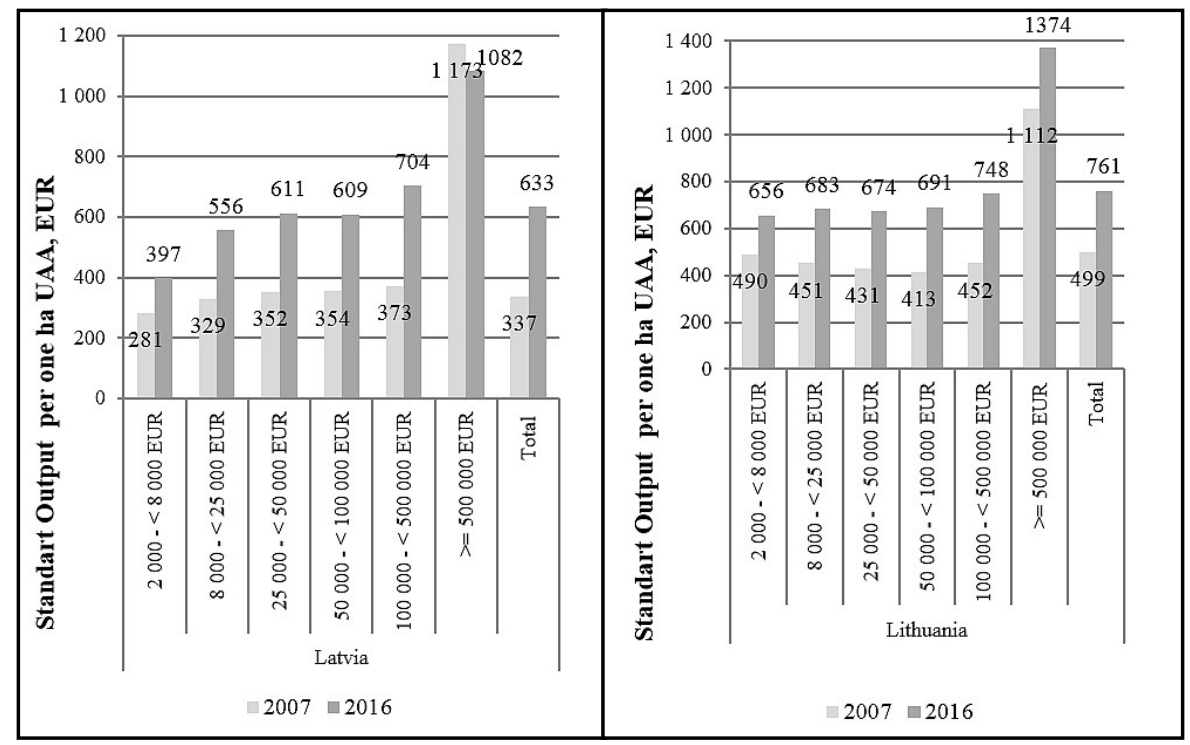

Source: Calculations based on FADN data (2007, 2016).

Fig. 2. Standard output per one ha UAA in Latvian and Lithuanian farms by size groups in 2007 and 2016, EUR. 
The growth of gross investment shows that farmers can modernize production processes and can increase the efficiency of economic activity. This leads to economic results of agricultural activity production and financial stability of the farms (Figure 3).

The development of agricultural gross investment is influenced by EU and national support for agricultural farms. According to the 2016 FADN study, the support provided to small farmers made up to almost one fifth of all gross investments in Lithuania and one third in Latvia.

The share of subsidies on investments to gross investments in all farms of Lithuania was $14.1 \%$, in Latvia - $13.6 \%$ in the year of 2016 (Figure 4). This share varies among different economic size groups as well. This share of Lithuanian small farms was equal to $20 \%$, in the large scale farms $-6.2 \%$; meanwhile in Latvia $-31.4 \%$ and $9 \%$ respectively. It should be noted that in the structure of agricultural investment, the share of self-financing of economic entities is increasing. Farmers themselves invest in renovation of agricultural machinery, industrial buildings, and other assets. Our findings illustrate that the support on investments in the small farms gives positive results. It is therefore necessary further to explore the impact of investments,

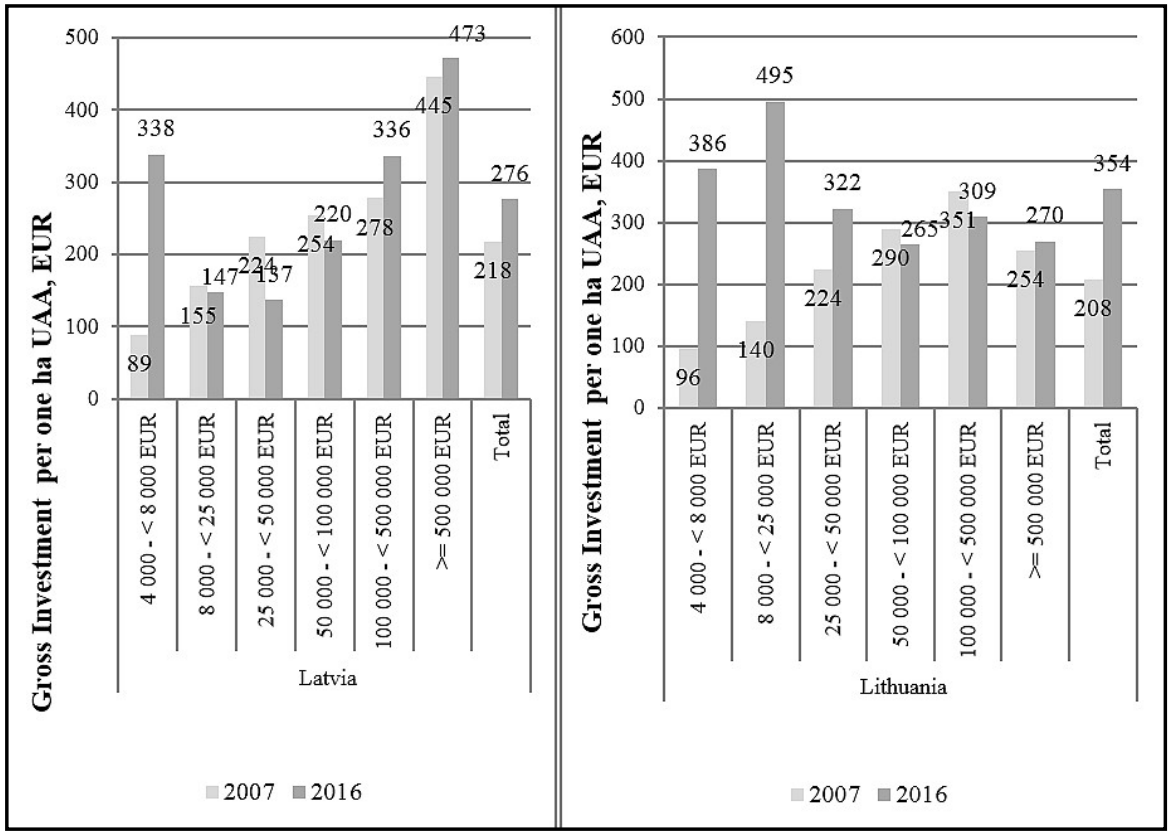

Source: Calculations based on FADN data $(2007,2016)$.

Figure 3: Gross Investment per one ha UAA in Latvian and Lithuanian farms in 2007 and 2016, EUR.

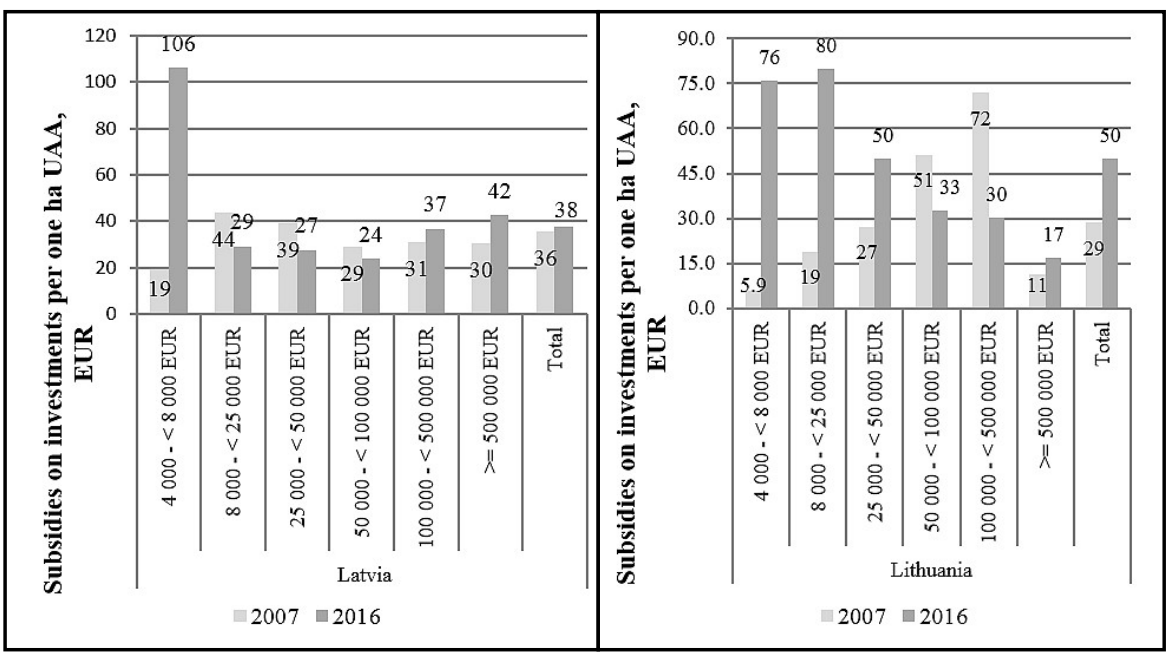

Source: Calculations based on FADN data (2007, 2016).

Figure 4: Subsidies on investments per one ha UAA in Latvia and Lithuania in 2007, 2016, EUR. 
as changes in the new RDP support rules for supporting small farms has occurred.

In addition, many of farms, having benefited from the EU and national support and previously acquired for modern high-performance equipment and production technologies, were able to improve their performance and generate revenue, allowing them to continue to modernize production processes at their own expense.

On the other hand, the 2007-2016 period was intensive in terms of the investment of small farms. Nevertheless, due to limited financial possibilities, the large amount of used equipment in comparison to new ones was acquired by them. "Investment in agricultural holdings" under the RDP, was provided only to farms purchasing new agricultural machinery. According to the current and the future RDP measures, both small farms and young farmers are targeted as high importance in agricultural viability terms, thus agricultural machinery sellers start more intensively provide farmers not only expensive machines orientated to large scale farms, but also smaller tractors and other equipment for small scale and start-up farmers. The possibilities of accumulation of own financial resources, EU and national support to small farms in future may determine the scope of modern production buildings and the availability of modern technical resources which in turn have to increase viability, social and economic sustainability of small farms both in Latvia and Lithuania.

\section{Conclusion}

When analyzing the linkage among sustainability, viability and resilience, it was found that the contribution of small farms to the agricultural sustainability is of particular importance. Therefore, in order to promote it, it is valuable to ensure and monitor the level of viability of small farms, which also stimulates the country's socio-economic resilience.

\section{Corresponding authors}

Yuriy Bilan

Rzeszow University of Technology

Powstańców Warszawy 12, 35-959 Rzeszów, Poland

Email:bilan@prz.edu.pl
The results of the research shows that in order to evaluate the viability of small farms it is necessary to spread indicators that allow identifying restrictions on the development of small farms, related with capital renewal, and create preconditions for a timely policy review. The selected indicators are intended to measure the upgrading of all forms of capital used by small farms; and that are involved in decision-making process on certain forms of capital renewal.

The analysis of selected economic indicators allowed identifying important aspects of viability of small farms. Small farms both in Latvia and Lithuania accumulate a large share of total agricultural employment. Gross farm income per one ha UAA in small farms is not much different than the average in total farms, and there is a tendency to decrease the differences among different farms size groups. Over the last decade, level of gross investment per ha in small farms has raised 3.8 times in Latvia and 4 times in Lithuania, and it is much higher than in medium size farms. Thus, small farms are in specific need of more support and accessibility to it through various instruments, which would help to increase viability of small farms in Latvia and Lithuania.

The analysis shows that a rate of subsidies on investment in small farms has grown over the period and situation has slightly improved. In Lithuania the trend is turned upside down from greatest support for larger farms in 2007 to opposite trend in 2016. As can be seen, changes in trends of subsidies on investment have consequences in income trends of small farms in Latvia and Lithuania. Although the high growth of subsidies on investment is most noticeable in small Lithuanian and Latvian farms, their level compared to the EU is extremely low, as the overall viability of these farms. This shows a necessity of a strong incentive for policy makers to prioritize small farms, while forming a national agricultural strategy and by creating RDP support structure.

\section{References}

[1] Agriculture, forestry and fishery statistics (2016) edition 2016. Statistical books. [Online]. Available: https:/ec.europa.eu/eurostat/documents/3217494/7777899/KS-FK-16-001-EN-N.pdf/cae3c56f53e2-404a-9e9e-fb5f57ab49e3 [Accessed: 28 Jul. 2018]. 
[2] Dillon, E. J., Hennessy, T., Buckley, C., Donnellan, T., Hanrahan, K., Moran, B. and Ryan, M. (2016) "Measuring progress in agricultural sustainability to support policy-making", International Journal of Agricultural Sustainability, Vol. 14, No. 1, pp.31-44. E-ISSN 1747-762X, ISSN 1473-5903. DOI 10.1080/14735903.2015.1012413.

[3] European Commission (2016) "Rural development 2014-2020", European Commission, Brussels. [Online]. Available: https://ec.europa.eu/agriculture/rural-development-2014-2020_en [Accessed: 13 Dec. 2018).

[4] Folke, C., Carpenter, S. R., Walker, B., Scheffer, M., Chapin, T. and Rockström, T. (2010) "Resilience thinking: integrating resilience, adaptability and transformability", Ecology and Society, Vol. 15, No. 4, pp. 20. ISSN 1708-3087. DOI 10.5751/ES-03610-150420.

[5] Galdeano-Gómez, E., Pérez-Mesa, J. and Godoy-Durán, A. (2016) "The social dimension as a driver of sustainable development: the case of family farms in southeast Spain", Sustainability Science, Vol. 11, No. 2, pp. 349-362. E-ISSN 1862-4057, ISSN 1862-4065. DOI 10.1007/s11625-015-0318-4.

[6] Gioia, A. and Rioufol, V. (2017) "Small Farms in Europe: Viable but Underestimated", AIAB Lazio Regional wert AG The Real Farming Trust Rurbans Soil Association Terre de Liens, 2017.

[7] Gołaś, J. (2017) "State aid schemes for small-scale agriculture in Poland under rural development programme for years 2014-2020”, Scientific Papers Series Management, Economic Engineering in Agriculture and Rural Development, Vol. 17, No. 3, E-ISSN 2285-3952, ISSN 2284-7995, .

[8] Guiomar, N., Godinho, S., Pinto-Correia, T., Almeida, M., Bartolini, F., Bezák, P., ... and Corazzin, M. (2018), "Typology and distribution of small farms in Europe: Towards a better picture", Land Use Policy, Vol. 75, pp. 784-798. ISSN 0264-8377. DOI 10.1016/j.landusepol.2018.04.012.

[9] Hanrahan, L., McHugh, N., Hennessy, T., Moran, B., Kearney, R., Wallace, M. and Shalloo, L. (2018) "Factors associated with profitability in pasture-based systems of milk production", Journal of Dairy Science, Vol. 101, No. 6, 5474-5485. E-ISSN 1525-3198, ISSN 0022-0302. DOI 10.3168/jds.2017-13223.

[10] Hooks, T., Macken-Walsh, A., McCarthy, O. and Power, C. (2017) "Farm level viability, sustainability and resilience: a focus on co-operative action and values-based supply chains", Studies in Agricultural Economics, Vol. 119, pp. 123-129. E-ISSN 2063-0476, ISSN 1418-2106. DOI 10.7896/j.1718.

[11] Kharlamova, G., Stavytskyy, A. and Zarotiadis, G. (2018) "The impact of technological changes on income inequality: the EU states case study. Journal of International Studies", Vol. 11, No. 2, pp. 76-94. ISSN 2071-8330. DOI 10.14254/2071-8330.2018/11-2/6.

[12] Kirschenmann, F., Stevenson, G. W., Buttel, F., Lyson, T. A. and Duffy, M. (2008) "Why Worry about the Agriculture of the Middle?", In: Food and the Mid-Level Farm: Renewing an Agriculture of the Middle (Lyson, T. A., Stevenson, G. W., Welsh, R., Eds.). ISBN-13 9780262122993. DOI 10.7551/mitpress/9780262122993.003.0001.

[13] Latruffe, L. and Bojnec, S. (2013) "Farm size, agricultural subsidies and farm performance in Slovenia", Land Use Policy, Vol. 32, No. 1, pp. 207-217. ISSN 0264-8377. DOI 10.1016/j.landusepol.2012.09.016.

[14] Lowder, S. K., Skoet, J. and Raney, T. (2015) "The Number, Size, and Distribution of Farms, Smallholder Farms, and Family Farms”, World Development, Vol. 87, No. Nov. 2016, pp. 16-29. ISSN 0305-750X. DOI 10.1016/j.worlddev.2015.10.041.

[15] Macken-Walsh, A. and Roche, B. (2012) “Facilitating Farmers'Establishment of Farm Partnerships: a Participatory Template" Teagasc, Oak Park, Carlow. [Online]. Available: https:/www.teagasc.ie/ media/website/publications/2012/Facilitating_Farmers_Establishment_of_Farm_Partnerships-a_ Participatory_Template.pdf[Accessed: 10 Dec. 2018).

[16] Melnikienè, R., Eičaite, O. and Volkov, A. (2018) "Sustainable development of agriculture: policy formulation and assessment of constraints“, Public Policy and Administration. Vol. 17, No. 2. E-ISSN 2029-2872, ISSN 1648-2603. 
[17] Morel, K., San Cristobal, M. and Légerd, F. G. (2017) "Small can be beautiful for organic market gardens: an exploration of the economic viability of French microfarms using MERLIN", Agricultural Systems, Vol. 158, pp. 39-49. ISSN 0308-521X. DOI 10.1016/j.agsy.2017.08.008.

[18] Morkūnas, M., Volkov, A. and Pazienza, P. (2018) "How Resistant is the Agricultural Sector? Economic Resilience Exploited", Economics and Sociology, Vol. 11, No 3, pp. 321-332. ISSN 2071-789X. DOI 10.14254/2071-789X.2018/11-3/19.

[19] Moroz, V., Ignat, A. and Lucasenco, E. (2014) "Small and large farms in the Republic of Moldova: trends and perspectives", Management Theory and Studies for Rural Business and Infrastructure Development. Vol. 36. No. 4. E-ISSN 2345-0355, ISSN 1822-6760. DOI 10.15544/mts.2014.085.

[20] Namiotko, V., Góral, J. and Soliwoda, M. (2017) "The economic situation of farms located in less favoured areas on the example of Lithuania and Poland", Agricultural and Resource Economics: International Scientific E-Journal, Vol. 3, No. 4, pp. 5-19. ISSN 2414-584X

[21] O’Donoghue, C., Devisme, S., Ryan M., Conneely R., Gillespi, P. and Vrolijk, H. (2016) "Farm economic sustainability in the European Union: A pilot study", Studies in Agricultural Economics. Vol. 118, No. 3, pp. 163-171. ISSN 1418-2106. DOI 10.7896/j.1631.

[22] Poór, J., Juhász, T., Machová, R., Bencsik, A. and Bilan, S. (2018) "Knowledge management in human resource management: Foreign-owned subsidiaries' practices in four CEE countries", Journal of International Studies, Vol. 11, No. 3, pp. 295-308. E-ISSN 2306-3483, ISSN 2071-8330. DOI 10.14254/2071-8330.2018/11-3/23

[23] Raišienè , A. G., Volkov, A., Skulskis, V. and Vilkè, R. (2018) "Representation of agricultural producers' interests: substantiation of the research construct", Ukrainian Food Journal, Vol. 7, No. 3, pp. 522-535. E-ISSN 2313-5891, ISSN 2304-974X. DOI 10.24263/2304-974X-2018-7-3-16.

[24] Rivza, B. and Kruzmetra, M. (2017) "Through economic growth to the viability of rural space" Entrepreneurship and Sustainability Issues, Vol 5., No. 2, pp. 283-296. E-ISSN 2345-0282. DOI 10.9770/jesi.2017.5.2(9).

[25] Ryan, M., Buckley, C., Dillon, E. J., Donnellan, T., Hanrahan, K., Hennessy, T. and Moran, B. (2014) "The development of farm-level sustainability indicators for Ireland using the Teagasc National Farm Survey", Contributed Paper prepared for presentation at the $88^{\text {th }}$ Annual Conference of the Agricultural Economics Society, AgroParisTech, France.

[26] Samberg, L. H., Gerber, J. S., Ramankutty, N., Herrero, M. and West, P. C. (2016) "Subnational distribution of average farm size and smallholder contributions to global food production", Environmental Research Letters, Vol. 11, No. 12. E-ISSN 1748-9326, ISSN 1748-9326. DOI 10.1088/1748-9326/11/12/124010

[27] Sarvašová, Z., Ali, T., Đorđević, I., Lukmine, D., Quiroga, S., Suárez, C., Hrib, M., Rondeux, J., Mantzanas, K. T. and Franz, K. (2017) "Natura 2000 payments for private forest owners in Rural Development Programmes 2007-2013 - a comparative view", Forest Policy and Economics, No. Sept 2017. ISSN 1389-9341. DOI 10.1016/j.forpol.2017.08.019.

[28] Seghesso, L. (2009) "The five dimensions of sustainability", Environmental Politics, Vol. 18, pp. 539-556. E- ISSN 1743-8934, ISSN 0964-4016. DOI 10.1080/09644010903063669.

[29] Soumaya, H. (2012) "The Effect of Debt, Firm Size and Liquidity on Investment - Cash Flow Sensitivity", International Journal of Accounting and Financial Reporting, Vol 2, No 2, pp. 1-16. ISSN 2162-3082. DOI 10.5296/ijafr.v2i2.2064.

[30] Stanczuk-Galwiaczek, M. (2018) "Main directions in the EU member states rural development policies: similarities and dissimilarities", $19^{\text {th }}$ International Scientific Conference "Economic Science for Rural Development 2018", No. 47, pp. 322-331. DOI 10.22616/ESRD.2018.038

[31] Svoboda, J., Lososová, J. and Zdeněk, R. (2016) "Subsidies on Investments in the EU Member States“, AGRIS on-line Papers in Economics and Informatics, Vol. 8, No. 4. ISSN 1804-1930. 
DOI 10.7160/aol.2016.080414.

[32] Tvaronavičienè, M. and Gatautis, R. (2017) "Peculiarities of Income Distribution in Selected Countries", Economics and Sociology, Vol. 10, No. 4, pp.113-123. E-ISSN 2306-3459, ISSN 2071-789X. DOI 10.14254/2071-789X.2017/10-4/9.

[33] Veveris, A. and Šapolaitè, V. (2017) "Accessibility of rural development programme support for small rural farms in Latvia and Lithuania", In Proceedings of the 2017 International Conference "Economic science for rural development", No. 44, Jelgava, LLU ESAF, 27-28 April 2017, pp. 345-352. E-ISSN 2255-9930, ISSN 1691-3078, ISBN 978-9984-48-260-6.

[34] Vrolijk, H. C. J., de Bont, C. J. A. M., Blokland, P. W. and Soboh, R. A. M. E. (2010) "Farm viability in the European Union: Assessment of the impact of changes in farm payments", LEI report 2010011, April 2010, Wageningen, p. 67. ISBN 978-90-8615-399-2.

[35] Walker, B. H., Holling, C.S., Carpenter, S. R. and Kinzig A. (2004) "Resilience, adaptability and transformability in social-ecological systems", Ecology and Society, Vol. 9, No. 2, pp. 5. ISSN 1708-3087. DOI 10.5751/ES-00650-090205. 